\title{
Walking A Kilometer In Their Shoes: An Exploration Of American And South Korean University Students' Expectations And Experiences
}

\author{
Carol J. Cumber, (E-mail: Carol_Cumber@sdstate.edu), South Dakota State University \\ April Brooks, South Dakota State University \\ Robert Thaler, South Dakota State University
}

\begin{abstract}
An exploratory study of university students from very different cultural backgrounds, attending universities in their home countries, was undertaken to assess their perceptions of multiculturalism, and their expectations and experiences as university students. Although a number of similarities existed, survey results indicated that the South Korean students were significantly more interested in multicultural issues. Survey results of American students indicated that even though their university offered myriad opportunities for increasing their understanding of diversity, multiculturalism and global issues, students lacked awareness of the opportunities and infrequently participated in the activities. This finding suggests that if a university is constrained by the non-diverse demography of its region, it will face a difficult task in motivating students to become globally aware and internationally competitive.
\end{abstract}

\section{Introduction}

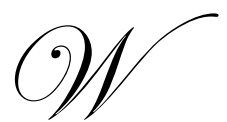

ith the recognition that the world is moving ever more rapidly toward a global economy, there has been increased emphasis on understanding and managing cultural differences (Harris \& Moran, 1987, 1996; Trompenaars, 1994; Earley \& Singh, 2000). To prepare students for this reality, universities are embracing opportunities for increasing students' understanding of diversity, multiculturalism and global issues. For those universities in rural venues such as are commonly found in the Northern Plains States, campuses tend to reflect the area, i.e., homogeneous and overwhelmingly white. In a study of multicultural and global perspectives in teacher education programs in NCATE-accredited land grant institutions in the United States (Igwe, 1999), one theme that emerged was that while universities expressed a desire to do more about addressing multicultural issues, some were handicapped due to the demography of their regions. For these universities, concerted efforts must be made if students are to achieve a broader perspective of multiculturalism and the world around them.

South Dakota State University has responded to this challenge. As part of its overall long-term strategic plan, the university has embraced the theme "To Lead Forward Through Excellence." A major goal of this plan is to have excellence in SDSU graduates, as determined, in part, by graduating students who are both "internationally competitive in academic preparation" and "globally informed and prepared for a diverse world" (Elliott, 2000:3).

This paper is the result of an exploratory study undertaken to assess university students' perceptions of multiculturalism, and expectations and experiences regarding other cultures. The authors were interested in learning whether students from very different cultural backgrounds were similar or dissimilar in regards to their expectations and experiences as college students. Two very different student groups were surveyed, one representing South 
Dakota State University in Brookings, SD, USA, the other from Chungnam National University, Daejon, Republic of South Korea.

\section{Literature Review}

Barrows (1981) summarized the results of extensive surveying of American students by the Educational Testing Service. Although 90\% of college students reported some exposure to a foreign language, there was no significant relationship between that exposure and what they knew about the wider world. They scored poorly on questions about energy, relations among nations, and religion. Many showed no knowledge of the history behind international issues. Finally, the students themselves believed that they had more exposure about international issues in the high school classroom than they gained in the college classroom. Jones and Smith (2001) concurred, contending that citizens around the world, despite the continuing globalization of our planet, remained remarkably traditional in outlook.

The need for better student preparation is widely recognized. The problem may be much more complicated than originally thought. For example, Rey-Von Allmen (2002) suggested that cultural heritage has multiple ownership. Identity is forged by the individual sometimes using elements from many cultures. Educational institutions should call on these dimensions of knowledge and experience to help "globalize" students. Given the complicated nature of the issues involved in globalization and multicultural education, evidence suggested that pedagogical techniques need to be refined. Sohoni (2003) stated that in order to improve course design, one must first understand one's own culture, and then understand globality as a complex system. Vasques Scalera (2000) concurred, stressing that both education and citizenship have a transformative nature, underscoring the importance of the learning process in facilitating students' transformations.

Schneider, (2003) in her summary of a report partially funded by the U.S. Department of Education, suggested revising the general education requirements to increase international content and increase foreign language programs. For faculty, recommendations included better training in advising, training in globalization issues via workshops and travel abroad opportunities, as well as including globalization components in the hiring and promotion process. This technique was also advised at the K-12 level (Kachel, 1995), where Zhang (2000) warned that teachers with limited knowledge of other cultures may perceive students' backgrounds as a handicap, thus helping to transmit that "handicap" into their school achievement. Alternatively, Harper, et. al. (1997) suggested a number of pedagogical strategies to address the issue of teaching diversity issues in a non-diverse setting. Some teachers discovered that different ethnic backgrounds react differently to teaching. Teacher training programs must learn to prepare future educators to deal with different learning styles by equipping them with a variety of teaching techniques. The new teacher needs new tools to reach the student (Ibarra, 2001).

Tanaka (1996) offered a cautionary note. His study, "The Impact of Multiculturalism on White Students," was based on research of 159 institutions of higher education. While institutional efforts to create a multicultural environment on campus seemed to have a positive effect, the diversity of both faculty and student populations tended to have a negative effect upon white students. He suggested that planned approaches work better than piecemeal approaches in order to find a way for white students to construct their identity in a way which is not pinned on race. Dougherty (2002) submitted that white instructors have a distinct challenge to face in presenting information about multicultural issues. His suggested solution was the incorporation of feminist pedagogy as a method of heightening student involvement because such pedagogy amplifies minority voices. Other challenges universities may face include the tendency of students to see other cultures as a threat to their search for cultural identity and affiliation. This suggested that students will be unreceptive to information about multiculturalism. Additionally, students may lack motivation to study other cultures and understand their perspective. Major barriers to intercultural understanding may include ethnocentrism and conservatism (Grunzweig and Reinhard, 2002). Kim (2002) emphasized that parental involvement in the Korean child's educational success was high, which resulted in high levels of motivation among the students. He also indicated that it is not uncommon for students to experience feelings of exhaustion and frustration during their education. 
Mestenhauser (Mestenhauser and Ellingboe, 1998) stressed that US students need to understand that various peoples interpret various experiences differently. In order to work in our interdependent world, US students must understand this. Their stereotypical thinking needs to be challenged. Research supported the argument that students' perspectives are influenced by personal experience (Barnett, 1999; Versluis, 2001). This implied that more opportunities for such personal experience with diversity needed to be created and implemented in the college curriculum. In an assessment of student skill development in the areas of intercultural adaptability and intercultural sensitivity, Williams (2002) compared students who had experienced study abroad with those who had not. Her results confirmed the hypothesis that students who study abroad had a better understanding of intercultural communication skills.

The literature available on student perception of the multicultural opportunities available to them and their exposure to globalization is generally broken down into two categories: general concerns about introducing students to multicultural experiences at all curricular levels, and suggestions of pedagogy to use when attempting this daunting task. This paper addresses the expectations and experiences of two groups of students, one at an American university, the other at a South Korean University.

\section{Methodology and Scope of Study}

Facilitated by a well-established faculty/student exchange agreement between South Dakota State University (SDSU), Brookings, SD and Chungnam National University (CNU), Daejon, Republic of South Korea, the authors participated in an exchange visit to Chungnam National University in May 2002 and conducted the Korean phase of the study during that time. The authors of this study were from the departments of Economics, History, and Animal and Range Sciences at SDSU. The authors were interested in comparing Korean and American university students' perceptions and experiences. A survey was developed that included demographic questions as well as questions pertaining to the following categories: University Preparation/Acceptance, University Experiences, Multi-Cultural Awareness, Student Exchange Perceptions, and Post-University Plans \& Expectations. Because it was written in English, they targeted the English language program at $\mathrm{CNU}$ as a viable venue in which to conduct their questioning. Dr. Sungshim Hong, an English professor at CNU, allowed the researchers into her classroom. Aware that the communication skills of the Korean students would vary, Dr. Hong previewed the survey and provided suggestions to increase its clarity. Dr. Hong received the survey instrument for distribution and completion by her students prior to the researchers' visit. This approach was used so that the students would not face time constraints in completing the survey, and could query their professor if there were any questions about survey content. Sixty-seven CNU students completed surveys.

At SDSU, a survey asking for the same information regarding perceptions and experiences at their university was distributed to students in a Western Civilization class in September 2002. One of the researchers explained the survey, was available to answer questions, and allowed students to complete the survey at their own pace during class time. Completion of the survey was voluntary; of 88 students registered for the class, 75 completed the survey.

Questions within the categories were opened ended, and the data were coded and tabulated to provide absolute and percentage results (see Appendix 1 for coding categories and meanings). Chi-square statistics were used to run a CHITEST to test for significant differences between the CNU and SDSU responses. Statistical results were reported at the 0.05 level of significance. Percentages may exceed $100 \%$ due to student responses in more than one category. $\mathrm{CNU} n=67$; SDSU $n=75$.

\section{Survey Responses/Discussion:}

When appropriate, representative quotes from the open ended survey question responses are provided in italics. The comments are in students' own words except where minor editing was required for purposes of clarity. 
How the student prepared for college: There is a significant difference in the amount of parental direction CNU students receive in comparison to SDSU students, with CNU parents seen as being more actively involved in their child's preparation for college.

A. Describe how you prepared during your elementary, junior and high school years so that you would be accepted into a university.

\begin{tabular}{|c|c|c|c|c|c|c|c|c|}
\hline CNU & Study-self & $\begin{array}{c}\text { Study- } \\
\text { Institution }\end{array}$ & $\begin{array}{c}\text { Parental } \\
\text { Direction* }\end{array}$ & Exposure & Nothing & Other* & $\begin{array}{c}\text { Misunder- } \\
\text { stood }\end{array}$ & $\begin{array}{c}\text { No } \\
\text { Answer }\end{array}$ \\
\hline & $26.87 \%$ & $83.58 \%$ & $23.88 \%$ & $2.99 \%$ & $5.97 \%$ & $8.96 \%$ & $5.97 \%$ & $0.00 \%$ \\
\hline SDSU & Study-self & $\begin{array}{c}\text { Study- } \\
\text { Institution }\end{array}$ & $\begin{array}{c}\text { Parental } \\
\text { Direction* }\end{array}$ & Exposure & Nothing & Other* & $\begin{array}{c}\text { Misunder- } \\
\text { stood }\end{array}$ & $\begin{array}{c}\text { No } \\
\text { Answer. }\end{array}$ \\
\hline & $22.67 \%$ & $84.00 \%$ & $1.33 \%$ & $1.33 \%$ & $12.00 \%$ & $32.00 \%$ & $1.33 \%$ & $0.00 \%$ \\
\hline
\end{tabular}

$*$ at the 0.05 level of significance

\section{CNU:}

During elementary school (for six years), I could enjoy my school life through making friends, doing art activities, etc. But when I was a middle school-high school student, I was forced to study only without any club activities. This is a big problem in Korean Education System until I entered a university I had to focus on studying only.As a high school student there are 8 regular classes at school from 8:30 a.m. until 7:30 p.m. After lunch 18:30 p.m. And I did study until 23:00 p.m. It's terrible! When I was a senior in high school, I did study all day, including Sunday. I took a test like the test for a university once a month. After that, I always checked my wrong answer and memorized in order to not make a mistake again. When I came back home after extra class I guess 23:30 or 24:00 p.m. My mother did not sleep to see her son.

\section{SDSU:}

Tried to keep up grade point averages and took special classes in high school that were recommended/required by local and state universities. Took the SAT/ACT Test in Junior year of high school and chose appropriate extra-curricular activities that would look good on a university application.

During elementary and junior high school I never really thought or prepared for being accepted into college because it seemed so far off. While in high school I tried to take as many higher level classes as possible. I also took some high school courses for college credit during my senior year.

I never did, based on the fact that I knew I was going to play football and I would get a scholarship to a university. And out of high school I knew that if I didn't get a scholarship I could always go to a Junior College and transfer out.

I never tried too hard at school. I did always get good grades though but I didn't have to try. The older I got the less I cared how well I did I just cared that it was enough to get accepted to a four year school.

Typical day of a CNU (SDSU) student: There is evidence in nearly every category to conclude that the students' days are similar. Exceptions are seen in the study of English or a foreign language and the use of computers. The former would be expected due to the language major of most of the CNU students. The lack of reporting the use of computers by SDSU students was surprising given the number of computer labs, state of the art wiring in dorms, etc. It was concluded that although the results suggests that SDSU students don't use computers in a typical day, the opposite is probably the case. It is likely that computer use is so commonplace that it didn't come to mind when responding to the question.

B. Describe a typical day of a Chungnam National University (South Dakota State University) student. 


\begin{tabular}{|c|c|c|c|c|c|c|c|c|}
\hline CNU & Classes & $\begin{array}{c}\text { General } \\
\text { Study }\end{array}$ & $\begin{array}{c}\text { Study } \\
\text { English* }\end{array}$ & Job & Leisure & Computer* & $\begin{array}{c}\text { Misunder- } \\
\text { Other }\end{array}$ \\
\hline & $91.04 \%$ & $64.18 \%$ & $19.40 \%$ & $44.78 \%$ & $79.10 \%$ & $14.93 \%$ & $17.91 \%$ & $7.46 \%$ \\
\hline SDSU & Classes & $\begin{array}{c}\text { General } \\
\text { Study }\end{array}$ & $\begin{array}{c}\text { Study } \\
\text { Foreign } \\
\text { Language* }\end{array}$ & Job & Leisure & Computer* & Other & $\begin{array}{c}\text { Misunder- } \\
\text { stood* }\end{array}$ \\
\hline & $97.33 \%$ & $80.00 \%$ & $0.00 \%$ & $36.00 \%$ & $81.33 \%$ & $0.00 \%$ & $17.33 \%$ & $0.00 \%$ \\
\hline
\end{tabular}

* at the 0.05 level of significance

\section{CNU:}

There are various students on CNU, boring, thinking, outgoing students. I'll introduce you to an outgoing student, In-joo. She always tried everything. She comes to CNU early at 7 a.m. She studies English with a CNU teacher. At school, she studies in her classes, and she takes auto-style chats with her friends and serfs the internet. At 7:00 p.m., she goes home until 9 p.m. She has a break and then she studies English for 3 hours.

I usually spend most of the time studying. I usually listen to lectures for four or five hour a day. But the lecture hour is different every day. It varies from just one hour to five hours. I participate in two clubs - one is central travel club and the other is English lover's club. I spend extra time associating with the club's members. Also, I spend two hours by tutoring after school. I spend much time talking with my friends or seniors, too. It is very valuable time to me.

\section{SDSU:}

I am a non-traditional student, so my day starts out getting my child to her school, first, every morning. From there, I get ready for my day \& do a little studying before classes start late morning. After a somewhat frustrating time finding parking, I attend my classes w/breaks in between for lunch and more study time. Then it's off to work I go. Wrapping the day off at home, cooking dinner, cleaning house, doing more homework and finally going to bed.

Wake up, shower, get ready to go to class. If you are a lucky student you may get breakfast. After you go to class then you either go back to dorms/house or to the library to study and do homework. If you are involved in sports you go to practice. Then at night you either cram for tests or go out to find a party - depending on if you did homework in the afternoon or not. Bedtime - start all over.

Interaction between faculty and students: There is evidence to conclude that the groups interact with faculty much the same, except that CNU students more often than SDSU students will consult their peers rather than a faculty member if they have questions. Interestingly, CNU students tended to comment on their reluctance to "bother" a professor with their questions, whereas if SDSU students were reluctant it was more likely due to a belief that it made them look bad or "uncool" if they asked questions.

C. Describe the interaction between the faculty and students both in and outside of class.

\begin{tabular}{|l|l|l|l|l|l|l|l|l|}
\hline CNU & In class & $\begin{array}{l}\text { Professor's } \\
\text { Office }\end{array}$ & Informal & Peers* & No contact & Other & $\begin{array}{l}\text { Misunder- } \\
\text { stood }\end{array}$ & No Answer \\
\hline & $44.78 \%$ & $56.72 \%$ & $26.87 \%$ & $5.97 \%$ & $13.43 \%$ & $19.40 \%$ & $2.99 \%$ & $0.00 \%$ \\
\hline SDSU & In class & $\begin{array}{l}\text { Professor's } \\
\text { Office }\end{array}$ & Informal & Peers* & No contact & Other & $\begin{array}{l}\text { Misunder- } \\
\text { stood }\end{array}$ & No Answer \\
\hline & $70.67 \%$ & $60.00 \%$ & $29.33 \%$ & $0.00 \%$ & $8.00 \%$ & $16.00 \%$ & $0.00 \%$ & $0.00 \%$ \\
\hline
\end{tabular}

- $\quad$ at the 0.05 level of significance 


\section{CNU:}

The interaction between the faculty and student is not formal. Strange to say, in Korean culture, asking question is thought to be a boast thing. The virtues of student are obedience and modesty, so Korean students are usually passive. In result, some Korean students feel the sense of unfamiliarity with faculty. Some of them haven't interaction with faculty in and outside of class. But there is an exception some students have interaction with faculty.When we meet the professor both in and outside of class, we pay our respects (say hello) to him or her. And when we have troubles with works or have some questions, we knock on the door of professor's office. But it's true that some Korean students feel constrained to talk with their professor. "Students must not even follow the shadow of their teacher." Is this Korean traditional proverb the reason? I don't know correctly. But it is clear the Korea is the country of courteous people in the East and the professors of CNU are honorable for us.

SDSU:

Faculty will say hi to you outside of class if they recognize you. I don't see much of my teachers outside of class. Teachers are well respected by students. Teachers are helpful and willing to work with you one-on-one.

This all depends on class size and the student's initiative to get to know the faculty. Almost all the faculty will take time for the students. You may have to make the first move though.

For the most part, interaction is impersonal, teachers usually see you are a number unless you make an effort to ask questions. Most students are "too cool" to ask questions.

Multi-cultural experiences available: The evidence indicates similarity between the two groups in informal presentations and socializing. There is a significant difference in the amount of formal presentations available, with CNU students more frequently identifying activities in the classroom. There also is a significant difference in the "no answer" category, which includes people who responded that they did not know what was available, with the SDSU students significantly more unaware of opportunities. This tells SDSU administration and faculty that there is still work to be done. Even though there is an office for diversity, an office for multicultural activities, an international programs office, student and faculty international exchange/travel opportunities and well-publicized calendars of diversity enhancement opportunities, many students are either not getting, or are ignoring the message.

D. What types of multi-cultural experiences are currently available to you on the CNU (SDSU) campus?

\begin{tabular}{|c|c|c|c|c|c|c|}
\hline CNU & $\begin{array}{c}\text { Formal } \\
\text { Presentation* }\end{array}$ & $\begin{array}{c}\text { Informal } \\
\text { Presentation }\end{array}$ & Socialize & Other* & $\begin{array}{c}\text { Misunder- } \\
\text { stood* }\end{array}$ & No answer* \\
\hline & $62.69 \%$ & $41.79 \%$ & $13.43 \%$ & $17.91 \%$ & $11.94 \%$ & $10.45 \%$ \\
\hline SDSU & $\begin{array}{c}\text { Formal } \\
\text { Presentation* }\end{array}$ & $\begin{array}{c}\text { Informal } \\
\text { Presentation }\end{array}$ & Socialize & Other* & $\begin{array}{c}\text { Misunder- } \\
\text { stood* }\end{array}$ & No answer* \\
\hline & $28.00 \%$ & $25.33 \%$ & $18.67 \%$ & $38.67 \%$ & $0.00 \%$ & $26.67 \%$ \\
\hline
\end{tabular}

$*$ at the 0.05 level of significance

Multi-cultural experiences participation: There is strong evidence to conclude that there is a significant difference between the groups in terms of taking advantage of multi-cultural experiences. The "no answer" column includes people who responded that they did not participate in any experiences. This suggests that the majority of SDSU students surveyed have not participated in any multicultural experiences available on their campus.

E. What types of multi-cultural experiences do you currently participate in on the CNU (SDSU) campus?

\begin{tabular}{|c|c|c|c|c|c|c|c|}
\hline CNU & $\begin{array}{c}\text { Foreign } \\
\text { Print }\end{array}$ & $\begin{array}{c}\text { Foreign } \\
\text { Entertainment }\end{array}$ & $\begin{array}{c}\text { Formal } \\
\text { Presentations* }\end{array}$ & $\begin{array}{c}\text { Informal } \\
\text { Presentations* }\end{array}$ & $\begin{array}{c}\text { Foreign } \\
\text { Students* }\end{array}$ & $\begin{array}{c}\text { English } \\
\text { club/class }\end{array}$ & $\begin{array}{c}\text { Foreign } \\
\text { Professor* }\end{array}$ \\
\hline & $0.00 \%$ & $2.99 \%$ & $40.30 \%$ & $31.34 \%$ & $4.48 \%$ & $25.37 \%$ & $29.85 \%$ \\
\hline
\end{tabular}




\begin{tabular}{|c|c|c|c|c|c|c|c|}
\hline SDSU & $\begin{array}{c}\text { Foreign } \\
\text { Print }\end{array}$ & $\begin{array}{c}\text { Foreign } \\
\text { Entertainment }\end{array}$ & $\begin{array}{c}\text { Formal } \\
\text { Presentations* }\end{array}$ & $\begin{array}{c}\text { Informal } \\
\text { Presentations* }\end{array}$ & $\begin{array}{c}\text { Foreign } \\
\text { Students* }\end{array}$ & $\begin{array}{c}\text { Foreign Lang. } \\
\text { club/class }\end{array}$ & $\begin{array}{c}\text { Foreign } \\
\text { Professor* }\end{array}$ \\
\hline & $0.00 \%$ & $0.00 \%$ & $10.67 \%$ & $6.67 \%$ & $10.67 \%$ & $6.67 \%$ & $1.33 \%$ \\
\hline \multirow[t]{2}{*}{$\mathrm{CNU}$} & Other & Misunderstood & No answer* & & & & \\
\hline & $26.87 \%$ & $5.97 \%$ & $1.49 \%$ & & & & \\
\hline \multirow[t]{2}{*}{ SDSU } & Other & Misunderstood & No answer* & & & & \\
\hline & $17.33 \%$ & $0.00 \%$ & $57.33 \%$ & & & & \\
\hline
\end{tabular}

$*$ at the 0.05 level of significance

Global awareness in the classroom: The evidence shows similarity in global awareness topics covered in the classroom. CNU students were more involved in internet research, and using foreign media to increase their knowledge of global issues. Again, there was a significant difference in the "no answer" column, which includes people who responded that nothing is offered (numerous SDSU students say that nothing is offered, even though there are formal records of many courses that include global components as part of the course pedagogy).

F. What is offered in your class to increase your global awareness?

\begin{tabular}{|c|c|c|c|c|c|c|c|}
\hline CNU & $\begin{array}{c}\text { Topics in } \\
\text { Class }\end{array}$ & $\begin{array}{c}\text { Internet } \\
\text { Research* }\end{array}$ & $\begin{array}{c}\text { Foreign } \\
\text { Media* }\end{array}$ & $\begin{array}{c}\text { Outside } \\
\text { University }\end{array}$ & Other & $\begin{array}{c}\text { Misunder- } \\
\text { stood }\end{array}$ & $\begin{array}{c}\text { No } \\
\text { Answer* }\end{array}$ \\
\hline & $65.67 \%$ & $16.42 \%$ & $19.40 \%$ & $4.48 \%$ & $32.84 \%$ & $2.99 \%$ & $1.49 \%$ \\
\hline SDSU & $\begin{array}{c}\text { Topics in } \\
\text { Class }\end{array}$ & $\begin{array}{c}\text { Internet } \\
\text { research* }\end{array}$ & $\begin{array}{c}\text { Foreign } \\
\text { Media* }\end{array}$ & $\begin{array}{c}\text { Outside } \\
\text { University }\end{array}$ & Other & $\begin{array}{c}\text { Misunder- } \\
\text { stood }\end{array}$ & $\begin{array}{c}\text { No } \\
\text { Answer* }\end{array}$ \\
\hline & $58.67 \%$ & $0.00 \%$ & $0.00 \%$ & $0.00 \%$ & $12.00 \%$ & $1.33 \%$ & $29.33 \%$ \\
\hline
\end{tabular}

$*$ at the 0.05 level of significance

Influence on each other country's culture: The majority of CNU and SDSU students agree that the countries influence each other. However, significantly more CNU students attest to the degree of influence. There is a significant difference in the number of students who say there is no influence; not one CNU student indicated this, whereas 21 SDSU students did. There is strong evidence across the columns to show a significant difference in the impact of one country on another. Opinions about this influence varied (see comments).

G. Do you believe there is American (Korean) influence on Korean (American) culture? If so, please give examples, and your opinion about this influence.

\begin{tabular}{|c|c|c|c|c|c|c|c|c|c|}
\hline $\mathrm{CNU}$ & Yes* & No* & $\begin{array}{c}\text { Americans in } \\
\text { Korea* }\end{array}$ & $\begin{array}{l}\text { American } \\
\text { Food* }\end{array}$ & $\begin{array}{c}\text { Media } \\
\text { Influence* }\end{array}$ & $\begin{array}{c}\text { American } \\
\text { Styles* }\end{array}$ & $\begin{array}{c}\text { Sex } \\
\text { Influences* }\end{array}$ & $\begin{array}{c}\text { Selfish- } \\
\text { ness }\end{array}$ & $\begin{array}{l}\text { English } \\
\text { Lang.* }\end{array}$ \\
\hline & $98.51 \%$ & $0.00 \%$ & $4.48 \%$ & $47.76 \%$ & $14.93 \%$ & $67.16 \%$ & $2.99 \%$ & $5.97 \%$ & $11.94 \%$ \\
\hline SDSU & Yes* & No* & $\begin{array}{l}\text { Koreans in } \\
\text { America* }\end{array}$ & $\begin{array}{l}\text { Korean } \\
\text { Food* }\end{array}$ & $\begin{array}{c}\text { Media } \\
\text { Influence* }\end{array}$ & $\begin{array}{l}\text { Korean } \\
\text { Styles* }\end{array}$ & $\begin{array}{c}\text { Sex } \\
\text { Influences* }\end{array}$ & $\begin{array}{l}\text { Selfish- } \\
\text { ness }\end{array}$ & $\begin{array}{l}\text { Korean } \\
\text { Lang.* }\end{array}$ \\
\hline & $58.67 \%$ & $28.00 \%$ & $8.00 \%$ & $20.00 \%$ & $1.33 \%$ & $17.33 \%$ & $0.00 \%$ & $0.00 \%$ & $0.00 \%$ \\
\hline $\mathrm{CNU}$ & \begin{tabular}{|c} 
Misunder- \\
stood*
\end{tabular} & $\begin{array}{c}\text { No } \\
\text { answer* }\end{array}$ & & & & & & & \\
\hline & $1.49 \%$ & $1.49 \%$ & & & & & & & \\
\hline SDSU & $\begin{array}{c}\begin{array}{c}\text { Misunder- } \\
\text { stood* }\end{array} \\
\end{array}$ & $\begin{array}{c}\text { No } \\
\text { answer* }\end{array}$ & & & & & & & \\
\hline & $10.67 \%$ & $6.67 \%$ & & & & & & & \\
\hline
\end{tabular}

\section{CNU:}


Korea has much influence from American, Korea and America have very close knit. Koreans hate and love America. For example, after Sault Lake Winter Olympic Korean hate America because of a short track racer, Ohno, so Korean's patriotism was higher, so they attached the Korean flags with their personal belongings and they didn't want to see the U.S. flags. Nevertheless, they always try to speak English fluently, and want to go especially America to learn orthodox English.

Along with the American emphasis on individual freedom, the belief in equality has a strong effect on the Korean culture. The idea of equality affects the relationships between husbands and wives. Although both husbands and wives have family duties, the wife has no power in family matter. But more wives start to be now able to support themselves and are freer to insist their views in family decisions.

I'm wondering about how often the American university students participates in their social affairs. Also I want to know how much convenience and treatment the American government offers the American University students. A few of the Korean university students are arrested or even died just for the reason that they were against the policy of the Korean government. The Korean university students' power is too weak. Especially CNU students, however, hardly tries to participate in Seoul affairs or campus activities actively. The signs in English line the streets, so many Koreans think subconsciously English is better than Korean. But the Korean language is very original. If Korea has economic strength, many other foreigners would want to learn the Korean language.

When the Korean war finished, America helped us recover from it. After that we've got American influences in many ways, culture, politic economy, etc. till now. So we are learning and using American English. I think we are too much Americanized today. Our taste already adjusted to American fast food, coke, pizza, hamburger... and so on. Also our teenagers want to have "Nike" shoes, and they are eager to meet American Pop stars. However, we have our beautiful traditional culture. We have to take pride and keep it well, and let Americans or other countries know our culture, conversely.

SDSU:

Many manufactured goods are made in Korea and shipped to the US. Korea is popular in trade with the United States. I believe that Mexico has the greatest cultural impact in us while China or Japan has the biggest technological impact. US.

I think there is a small influence by Korea on American culture. Many foods from Korea have come to the

Yes, food, cheap labor, and kids for Americans to adopt.

Korean influence in some cartoons, martial arts, media and labor markets. I have no educated opinion about this.

Exchange student concerns: The students shared concerns in most areas, except in regards to safety, where significantly more American students were concerned about being safe. South Korean students were more concerned about the availability of certain programs of study and whether they would have difficulties in learning about and/or understanding American culture.

H. If you were to be an exchange student to the United States (Korea), what would be your greatest concern and why?

\begin{tabular}{|c|c|c|c|c|c|c|c|c|c|c|}
\hline CNU & $\begin{array}{c}\text { Food } \\
\text { Differences }\end{array}$ & Fitting In & $\begin{array}{c}\text { Money } \\
\text { Issues }\end{array}$ & $\begin{array}{c}\text { Safety in } \\
\text { America* }\end{array}$ & $\begin{array}{c}\text { Holly- } \\
\text { wood }\end{array}$ & $\begin{array}{c}\text { Study* } \\
\text { Avail-ability }\end{array}$ & $\begin{array}{c}\text { Job } \\
\text { Experience }\end{array}$ & Travel & Major & Culture* \\
\hline & $7.46 \%$ & $38.81 \%$ & $5.97 \%$ & $4.48 \%$ & $7.46 \%$ & $17.91 \%$ & $0.00 \%$ & $5.97 \%$ & $0.00 \%$ & $29.85 \%$ \\
\hline SDSU & $\begin{array}{c}\text { Food } \\
\text { Differences }\end{array}$ & Fitting In & $\begin{array}{c}\text { Money } \\
\text { Issues }\end{array}$ & $\begin{array}{c}\text { Safety in } \\
\text { Korea* }\end{array}$ & & $\begin{array}{c}\text { Study* } \\
\text { Avail-ability }\end{array}$ & $\begin{array}{c}\text { Job } \\
\text { Experience }\end{array}$ & Travel & Major & Culture* \\
\hline
\end{tabular}




\begin{tabular}{|c|c|c|c|c|c|c|c|c|c|c|}
\hline & $4.00 \%$ & $60.00 \%$ & $1.33 \%$ & $18.67 \%$ & $\mathrm{n} / \mathrm{a}$ & $4.00 \%$ & $0.00 \% \%$ & $5.33 \%$ & $1.33 \%$ & $13.33 \%$ \\
\hline $\mathrm{CNU}$ & Other & $\begin{array}{l}\text { Misunder- } \\
\text { stood* }\end{array}$ & & & & & & & & \\
\hline & $13.43 \%$ & $8.96 \%$ & & & & & & & & \\
\hline SDSU & Other & $\begin{array}{l}\text { Misunder- } \\
\text { stood* }\end{array}$ & & & & & & & & \\
\hline & $20.00 \%$ & $0.00 \%$ & & & & & & & & \\
\hline
\end{tabular}

Exchange student positive expectations: The evidence shows similar responses regarding job assistance and travel availability, but significant differences relative to interest in learning the language, culture, study habits, and making friends. SDSU students' comments included that they didn't think they would have to worry about learning the language, perhaps an assumption about the pervasiveness of the English language around the world. The CNU students commented much more often on looking forward to making friends. Interestingly, whereas many CNU students were concerned that they would have difficulty in learning about or understanding another culture, this was what the majority of SDSU students listed as what they most looked forward to.

I. If you were to be an exchange student to the United States (Korea), what would you most look forward to, and why?

\begin{tabular}{|c|c|c|c|c|c|c|c|c|c|}
\hline CNU & $\begin{array}{c}\text { Learning } \\
\text { English* }\end{array}$ & Culture* & $\begin{array}{c}\text { Study* } \\
\text { Habits }\end{array}$ & Friends* & $\begin{array}{c}\text { Job } \\
\text { assistance }\end{array}$ & $\begin{array}{c}\text { Travel } \\
\text { availability* }\end{array}$ & Other & $\begin{array}{c}\text { Misunder- } \\
\text { stood }\end{array}$ & $\begin{array}{c}\text { No } \\
\text { answer }\end{array}$ \\
\hline & $40.30 \%$ & $38.81 \%$ & $8.96 \%$ & $26.87 \%$ & $4.48 \%$ & $10.45 \%$ & $13.43 \%$ & $2.99 \%$ & $0.00 \%$ \\
\hline SDSU & $\begin{array}{c}\text { Learning } \\
\text { Korean* }\end{array}$ & Culture* & $\begin{array}{l}\text { Study* } \\
\text { Habits }\end{array}$ & Friends* & $\begin{array}{c}\text { Job } \\
\text { assistance }\end{array}$ & $\begin{array}{c}\text { Travel } \\
\text { availability* }\end{array}$ & Other & $\begin{array}{c}\text { Misunder- } \\
\text { stood }\end{array}$ & $\begin{array}{c}\text { No } \\
\text { answer }\end{array}$ \\
\hline & $2.67 \%$ & $70.67 \%$ & $0.00 \%$ & $4.00 \%$ & $0.00 \%$ & $20.00 \%$ & $17.33 \%$ & $0.00 \%$ & $4.00 \%$ \\
\hline
\end{tabular}

$*$ at the 0.05 level of significance

\section{CNU:}

I would look forward to the freedom. For instance, in the class, I don't have to see how the wind blows, I can speak my opinions freely. Then my personality would be changed.

Frankly speaking, Hollywood is the first place where I want to visit. I love to go to the movies, especially Hollywood's movies. Some are very fun and others move me. I want to see famous actors and actresses.

SDSU:

I would look forward to a new adventure and I would be proud of myself for stepping out of my comfort zone. I would look forward to learning new things and being able to take that home with me.

Educating American (Korean) students: There is strong evidence to show that the two groups would want each other to know their language ability (or lack thereof), viewpoints, and recreational interests. CNU students were significantly more interested in learning about American views on topics such as personal relationships, dating, and marriage.

J. What would be the most important thing about you that you would want American (Korean) university students to know and why?

\begin{tabular}{|c|c|c|c|c|c|c|c|c|}
\hline CNU & $\begin{array}{c}\text { Language } \\
\text { Ability }\end{array}$ & $\begin{array}{c}\text { Food } \\
\text { Differences }\end{array}$ & $\begin{array}{c}\text { Personal } \\
\text { Relationships* }\end{array}$ & $\begin{array}{c}\text { View- } \\
\text { points }\end{array}$ & $\begin{array}{c}\text { Recreational } \\
\text { Interests }\end{array}$ & Other & $\begin{array}{c}\text { Misunder- } \\
\text { stood* }\end{array}$ & $\begin{array}{c}\text { No } \\
\text { answer }\end{array}$ \\
\hline & $8.96 \%$ & $7.46 \%$ & $5.97 \%$ & $28.36 \%$ & $8.96 \%$ & $41.79 \%$ & $13.43 \%$ & $5.97 \%$ \\
\hline
\end{tabular}




\begin{tabular}{|c|c|c|c|c|c|c|c|c|}
\hline SDSU & $\begin{array}{c}\text { Language } \\
\text { Ability }\end{array}$ & $\begin{array}{c}\text { Food } \\
\text { Differences }\end{array}$ & $\begin{array}{c}\text { Personal } \\
\text { Relationships* }\end{array}$ & $\begin{array}{c}\text { View- } \\
\text { points }\end{array}$ & $\begin{array}{c}\text { Recreational } \\
\text { Interests }\end{array}$ & $\begin{array}{c}\text { Other } \\
\text { stood* }\end{array}$ & $\begin{array}{c}\text { No } \\
\text { answer }\end{array}$ \\
\hline & $2.67 \%$ & $1.33 \%$ & $0.00 \%$ & $40.00 \%$ & $8.00 \%$ & $62.67 \%$ & $2.67 \%$ & $1.33 \%$ \\
\hline
\end{tabular}

\section{CNU:}

I'm a Korean and like kaegogy (dog) a lot. Of course, I love pets, especially dogs. Kaegogy is a kind of food and a part of our culture. I do want them to understand that kaegogy is a part of our culture. We are not savages but culturists.

SDSU:

I would like to set an example that Americans are nice, loving, and accepting people, and that our lives are exciting.

My grandfather was a fighter ace in the USAF who helped to defend South Korea in the Korean war.

That I am a small town girl and I go to a small town college that did not really get a whole lot of diversity growing up.

That I am thoughtful, non-judgmental, but most of all, curious about them and their culture.

I would want them to know how awesome it is living in a free country and having my independence. We can marry who we want and pretty much do anything else unless it is against the law.

That many Americans are hard workers, and America isn’t as bad as most other cultures believe we are.

I'd want them to know that I don't mean to offend with any of my uninformed/ignorant questions.

Educating yourself: There is very strong evidence to conclude that the two groups want to know similar things about each other.

K. What would be the most important thing that you would want to know about American (Korean) university students and why?

\begin{tabular}{|c|c|c|c|c|c|c|c|}
\hline CNU & $\begin{array}{c}\text { Learning style } \\
\text { differences }\end{array}$ & $\begin{array}{c}\text { Lifestyle } \\
\text { Differences }\end{array}$ & $\begin{array}{c}\text { Political } \\
\text { Differences }\end{array}$ & Demographics & Other & $\begin{array}{c}\text { Misunder- } \\
\text { stood }\end{array}$ & No answer \\
\hline & $40.30 \%$ & $46.27 \%$ & $4.48 \%$ & $4.48 \%$ & $28.36 \%$ & $5.97 \%$ & $5.97 \%$ \\
\hline SDSU & $\begin{array}{c}\text { Learn style } \\
\text { differences }\end{array}$ & $\begin{array}{c}\text { Lifestyle } \\
\text { Differences }\end{array}$ & $\begin{array}{c}\text { Political } \\
\text { Differences }\end{array}$ & Demographics & Other & $\begin{array}{c}\text { Misunder- } \\
\text { stood }\end{array}$ & No answer \\
\hline & $24.00 \%$ & $57.33 \%$ & $6.67 \%$ & $1.33 \%$ & $24.00 \%$ & $2.67 \%$ & $5.33 \%$ \\
\hline
\end{tabular}

\section{CNU:}

The most important thing to want to know about American university students is how to love. I think their ideas about the other sex is different from us. I wonder how they learn sex education and how they think of marriage and divorce.

SDSU: 
I would want to know what is most important to them in their lives. I would like to recheck my own priorities and see if I can learn new values from them.

Family's expectations: Students were asked for their family's expectations of them once they graduated. There is significant difference between the groups relative to the expectation that the student would become a teacher (not one SDSU student named this). Given that the majority of CNU survey respondents were language majors and female, this finding is not surprising. Both groups are similar in the expectation to get a good job. There is a difference in the "set role expectation" category in that no SDSU student mentioned set role expectations, such as a "proper job for a woman". SDSU students were more likely to indicate that their family wished them good health and fulfillment on the job.

L. What are your family's expectations of you?

\begin{tabular}{|l|c|c|c|c|c|c|c|c|c|c|}
\hline CNU & $\begin{array}{c}\text { Good } \\
\text { job }\end{array}$ & $\begin{array}{c}\text { Become } \\
\text { Teacher* }\end{array}$ & $\begin{array}{c}\text { Take Care of } \\
\text { self* }\end{array}$ & $\begin{array}{c}\text { Hard } \\
\text { working }\end{array}$ & $\begin{array}{c}\text { Marry } \\
\text { well }\end{array}$ & $\begin{array}{c}\text { Student } \\
\text { sets Goals }\end{array}$ & $\begin{array}{c}\text { Set Role } \\
\text { Expectation* }\end{array}$ & Other* & $\begin{array}{c}\text { Misunder- } \\
\text { stood* }\end{array}$ & $\begin{array}{c}\text { No } \\
\text { Answer }\end{array}$ \\
\hline & $23.88 \%$ & $32.84 \%$ & $25.37 \%$ & $7.46 \%$ & $7.46 \%$ & $35.82 \%$ & $8.62 \%$ & $16.42 \%$ & $4.48 \%$ & $1.49 \%$ \\
\hline SDSU & $\begin{array}{c}\text { Good } \\
\text { job }\end{array}$ & $\begin{array}{c}\text { Become } \\
\text { Teacher* }\end{array}$ & $\begin{array}{c}\text { Take Care of } \\
\text { self* }\end{array}$ & $\begin{array}{c}\text { Hard } \\
\text { working } \\
*\end{array}$ & $\begin{array}{c}\text { Marry } \\
\text { well }\end{array}$ & $\begin{array}{c}\text { Student } \\
\text { sets Goals }\end{array}$ & $\begin{array}{c}\text { Set Role } \\
\text { Expectation* }\end{array}$ & Other* & $\begin{array}{c}\text { Misunder- } \\
\text { stood* }\end{array}$ & $\begin{array}{c}\text { No } \\
\text { Answer }\end{array}$ \\
\hline & $26.67 \%$ & $0.00 \%$ & $49.33 \%$ & $21.33 \%$ & $5.33 \%$ & $30.67 \%$ & $0.00 \%$ & $44.00 \%$ & $0.00 \%$ & $1.33 \%$ \\
\hline
\end{tabular}

$*$ at the 0.05 level of significance

\section{Conclusion}

The primary objective of this study was to explore whether students from different cultural backgrounds, who were attending universities in their home country, were similar or dissimilar in their expectations and experiences as college students. While some differences existed, there also were many similarities. The CNU students expressed interest in multicultural issues and were motivated to participate in activities that increased their awareness and knowledge of other cultures. A principle concern for Korean students dealt with mastery of the English language, not surprising given that the majority of those surveyed were language majors. It was interesting to note, however, that $\mathrm{CNU}$ student responses indicated that although they were conflicted about the English language and the potential of American influences eroding their culture, nearly 64\% indicated that they studied English everyday, and over 13\% indicated that passing an English exam would be a requirement in acquiring a good job in South Korea. CNU student responses supported the literature that parental involvement in the Korean child's educational success was high. That Korean students frequently experience feelings of exhaustion and frustration during their education was also confirmed.

Regarding the SDSU students, results supported the literature that it's common for U.S. students to be relatively unmotivated in studying other cultures and learning about their experiences and perspectives. SDSU and universities like it face a difficult task. Although they may be actively encouraging increased global awareness in terms of faculty development, training and workshops, international travel opportunities, increased global components in the classroom, myriad multicultural activities, etc., the students may be reluctant to take advantage of those opportunities. These universities will continue to face a difficult task to graduate students who are "internationally competitive" and "globally aware," but hopefully, with more emphasis on multicultural issues and experiences, the globalization of university students will be enhanced.

\section{Study Limitations}

Although some of the results were intriguing, the exploratory nature of this study needs to be recognized, and care taken to not draw broad conclusions. There were several aspects that could impact the results. These included factors such as age differences, in that while there were a similar number of 21 years olds surveyed, on average CNU students were older, with $70 \% 22$ or older, whereas SDSU students had only $30 \%$ older than 21 . There 
were significantly more females in the CNU group than the SDSU group, $86.57 \%$ compared to $44.00 \%$. While the vast majority of CNU students (89.55\%) were English majors, the SDSU students surveyed represented 44 different majors in seven different colleges. Although the majority of the students at both universities (CNU 71.64\%, SDSU $53.33 \%$ ) had not traveled outside their home country, it should be noted that although more SDSU students had traveled outside their home country than Korean students, Canada is only a five hour drive to the north (a relatively short distance for residents of the northern plains region of the U.S.), and Mexico is a popular spring break location. While $4.48 \%$ of CNU students had traveled to the U.S., no SDSU student had traveled to South Korea.

In general, CNU students gave much more thorough and detailed answers, while the SDSU students' responses were often vague and brief. This could be due to the fact that CNU students knew that foreign professors were going to come into their classroom to query them about their answers.

For anyone interested in pursuing a comparison of American and Korean students, "American/Korean Contrasts: Patterns and Expectations in the US and Korea," by Susan Oak and Virginia Martin (2002) is a useful read. It discusses the Eastern/Western cultural differences such as self versus group, morality, patterns of personal interaction, etc. Whether one is teaching in these groups, working or studying with them, this book is vital in helping the "foreigner" become acclimatized.

\section{References:}

1. Barnett, E. 1999. "Student Learning in a Community College Multicultural Course." Ph.D. diss., University of Washington, abstract in Dissertation Abstracts International, 60(04A):0983.

2. Barrows, T. 1981. What College Students Know and Believe About Their World. New York: Change Magazine Press.

3. Dougherty, K. 2002. "Giving Voice: The Challenge for a White Instructor in a Multicultural Course." Michigan Sociological Review, 16:63-77. Fall.

4. Earley, P. and Singh, H. (eds). 2000. Innovations in International and Cross-Cultural Management. Thousand Oaks, CA: Sage Publishing.

5. Elliott, Peggy Gordon. 2000. The Lead Forward Land-Grant 2000-2001: A Year of Following Through. South Dakota State University. Published by the Office of the President.

6. Grunzweig, W. and Rinehart, N. (eds). 2002. Rockin' in Red Square: Critical Approaches to International Education in the Age of Cyberculture. Munster: Lit Verlag.

7. Harper, A., Cumber, C., Braithwaite, C., and Braithwaite, D. 1997. "Here?": Strategies for Teaching About Cultural Diversity in Non-Diverse Regions." Journal of Professional Studies, 4(1):45-56.

8. Harris, P. and Moran, R. 1987. Managing Cultural Differences: High-Performance Strategies for Today's Global Manager. Houston: Gulf Publishing.

9. Harris, P. and Moran, R. 1996. Managing Cultural Differences: Leadership Strategies for a New World of Business. Houston: Gulf Publishing.

10. Ibarra, R. 2001. Beyond Affirmative Action: Reframing the Context of Higher Education. The University of Wisconsin Press. Accessed through TOMORROW'S PROFESSOR(SM) LISTSERV, R. Reis (ed). Sponsored by The Stanford University Center for Teaching and Learning. http://ctl.stanford.edu.

11. Igwe, C. 1999. "Multicultural and Global Perspectives in Teacher Education Programs in NCATE-accredited Land-grant Institutions in the United States of America.” Ed.D. diss., University of Nevada, abstract in Dissertation Abstracts International, 61(02A):440.

12. Jones, F. and Smith, P. 2001. "'Diversity and Commonality in National Identities: An Exploratory Analysis of Cross-National Patterns." Journal of Sociology, 37(1):45-63. May.

13. Kachel, L. 1995. "A Policy and Implementation Analysis of Multicultural, Nonsexist Education.” Ed.D. diss., Drake University, abstract in Dissertation Abstracts International, 56(10A):3857.

14. Kim, E. 2002. "The Relationship between Parental Involvement and Children's Educational Achievement in the Korean Immigrant Family.” Journal of Comparative Family Studies, 33(4):529-540.

15. Mestenhauser, J. and Ellingboe, B. (eds). 1998. Reforming the Higher Education Curriculum: Internationalizing the Campus. American Council on Education, Phoenix: Oryx Press.

16. Oak, S. and Martin, V. 2002. American/Korean Contrasts. Elizabeth, NJ: Hollym International Corporation.

17. Rey-Von Allmen, M. 2002. "Intercultural Education: A Challenge and Necessity for Our Multicultural Society." Migracijske I ethicke teme (Migration and Ethical Themes), 18(1):85-98. March. 
18. Sarles, H. 1998. "Explaining Ourselves through Others' Cultural Visions." Chapter 10 in Mestenhauser, J. and Ellingboe, B. (eds). Reforming the Higher Education Curriculum: Internationalizing the Campus. American Council on Education, Phoenix: Oryx Press.

19. Schneider, A. 2003. "Internationalizing Teacher Education: What Can Be Done?” A summary research report on the Undergraduate Training of Secondary School Teachers presented at the Global Challenges and U.S. Higher Education Conference, Durham, NC. http://www.aacte.org/Global_International/ schneider_summary.pdf. Accessed 1/19/04.

20. Sohoni, D. 2003. "'Internationalizing' the Classroom: Meaning and Methods." Paper presented at the annual meeting of the Southern Sociological Society, New Orleans, LA.

21. Tanaka, G. 1996. "The Impact of Multiculturalism on White Students.” Ph.D. diss., The University of California at Los Angeles, abstract in Dissertation Abstracts International, 57(05A):1980.

22. Trompenaars, F. 1994. Riding the Waves of Culture: Understanding Diversity in Global Business. Chicago: Irwin Professional Publishing.

23. Vasques Scalera, C. 2000. "Democracy, Diversity, Dialogue: Education for Critical Multicultural Citizenship." Ph.D. diss., University of Michigan, abstract in Dissertation Abstracts International, 61(561A):2.

24. Versluis, D. 2001. "Exploring College Students' Understanding of Diversity: The Effect of Experience, Interventions, and Encapsulation." Ed.D. diss., Oregon State University. Dissertation Abstracts International, 62(08A):2665.

25. Williams, T. 2002. "Exploring the Impact of Study Abroad on Students' Intercultural Communication Skills: Adaptability and Sensitivity." M.A. thesis, University of Missouri, abstract in Masters Abstracts International, 41(01):15.

26. Zhang, Y. 2000. “An International Study of Teachers' Perspectives and Students' Achievement.” Ph.D. diss., Pennsylvania State University, abstract in Dissertation Abstracts International, 61(4728-9A):12.

\section{Appendix 1}

\section{Coding Key:}

\begin{tabular}{|c|c|c|}
\hline Question & Categories & Meaning \\
\hline \multirow[t]{8}{*}{ A } & Study-Self & Self-directed study such as reading, cramming, studying languages \\
\hline & Study-Institution & Structured assistance such as tutoring, classes, private institutes \\
\hline & Parental Direction & Parental direction in terms of pressure or support \\
\hline & Exposure & $\begin{array}{l}\text { Exposure to events outside the classroom such as sightseeing, increased cultural } \\
\text { awareness }\end{array}$ \\
\hline & Nothing & Did nothing special \\
\hline & Other & $\begin{array}{l}\text { Used to code responses that were very specific to the individual and didn't fit a } \\
\text { general category }\end{array}$ \\
\hline & Misunderstood & $\begin{array}{l}\text { Use to code responses when respondent obviously didn't understand the question } \\
\text { (choice in every question) }\end{array}$ \\
\hline & No Answer & (choice in every question) \\
\hline \multirow[t]{6}{*}{ B } & Classes & Formal classes \\
\hline & General study & At home, at the library, or in study groups \\
\hline & Study English/Foreign Language & Study and practice English at CNU, or at any foreign language at SDSU \\
\hline & Job & Part of full-time employment \\
\hline & Leisure & Partying, socializing with friends, sports, exercise \\
\hline & Computer & Computer time: internet, email, developing computer skills \\
\hline \multirow[t]{5}{*}{$\mathbf{C}$} & In class & Ask questions in class \\
\hline & Professor's Office & Visit professor in his/her office \\
\hline & Informal & Emails, in hallway, at social events \\
\hline & Peers & Ask peers questions instead of, or before asking professors \\
\hline & No Contact & Too shy, no need \\
\hline \multirow[t]{3}{*}{ D } & Formal Presentations & Formal presentations such as classes, seminars, special lectures \\
\hline & Informal Presentations & Informal presentations such as concerts, movies, plays \\
\hline & Socialize & Lunches, partying, clubs, talk to instructors, foreigners met at bars and clubs \\
\hline \multirow[t]{4}{*}{$\mathbf{E}$} & Foreign Print & Foreign books, magazines \\
\hline & Foreign Entertainment & Foreign movies and concerts \\
\hline & Formal Presentation & Classes, seminars, special lectures \\
\hline & Informal Presentation & Concerts, movies, plays \\
\hline
\end{tabular}




\begin{tabular}{|c|c|c|}
\hline & Foreign Students & Interaction with foreign students on campus \\
\hline & $\begin{array}{l}\text { English/Foreign Language Club } \\
\text { or class }\end{array}$ & English club and English classes; at SDSU-foreign language classes \\
\hline & Foreign Professors & Foreign teachers at the university \\
\hline \multirow[t]{4}{*}{$\mathbf{F}$} & Topics in Class & Includes class assignments \\
\hline & Internet Research & Assignments requiring internet research \\
\hline & Foreign Media & Foreign movies and print media \\
\hline & Outside University & Outside opportunities not arranged by the university \\
\hline \multirow[t]{7}{*}{ G } & $\begin{array}{l}\text { Americans in Korea; Koreans in } \\
\text { America }\end{array}$ & $\begin{array}{l}\text { The influence that comes from having someone in one country travel to another } \\
\text { country }\end{array}$ \\
\hline & American Food/ Korean Food & American foods in Korea/Korean foods in America \\
\hline & Media Influences & Media influences, especially on the young \\
\hline & American Styles & Such as hair, clothing, body images, language \\
\hline & Sexual Influences & In terms of gender issues \\
\hline & Selfishness & Selfishness in terms of imposing one's culture on another \\
\hline & $\begin{array}{l}\text { English Language/ Korean } \\
\text { Language }\end{array}$ & $\begin{array}{l}\text { Emphasis on the English language/emphasis on the Korean language in the other's } \\
\text { country }\end{array}$ \\
\hline \multirow[t]{10}{*}{$\mathbf{H}$} & Food Differences & In relation to not being able to adapt to the other country's food choices. \\
\hline & Fitting in & Homesickness, adapting, understanding, embarrassment, inadequate language skills \\
\hline & Money Issues & Not having enough money to be able to live in the country \\
\hline & $\begin{array}{l}\text { Safety in America/ } \\
\text { Safety in Korea }\end{array}$ & Fearing for one's safety \\
\hline & Hollywood & Going to Hollywood, influence of TV and movies \\
\hline & Study Availability & Specific study availability, literature, science \\
\hline & Job Experience & Lack of available of jobs. \\
\hline & Travel & Being able to "get around" in the country \\
\hline & Major & Learning about things related to their major area of study \\
\hline & Culture & Difficulty in learning about and understanding the culture \\
\hline \multirow[t]{6}{*}{$\mathbf{I}$} & Learn English/ Learn Korean & Learning the other country's language \\
\hline & Culture & Learning about culture and cultural differences \\
\hline & Study Habits & Learning about other's study habits \\
\hline & Friends & Making friends \\
\hline & Job assistance & Getting assistance in finding a job \\
\hline & Travel availability & Opportunities for travel in the country \\
\hline \multirow[t]{5}{*}{$\mathbf{J}$} & Language Ability & In relation to lack of good language skills \\
\hline & Food Differences & That there may be problems liking the country's food \\
\hline & Personal Relationships & The importance of personal relationships, marriage, dating issues \\
\hline & Viewpoints & In terms of whether they were open or narrow-minded, tolerance, political views \\
\hline & Recreational Interests & Interest in hobbies and sports \\
\hline \multirow[t]{4}{*}{$\mathbf{K}$} & Learning style differences & In relation to preferred teaching styles, school life, study habits \\
\hline & Lifestyle differences & In relation to hobbies, cultural issues sense of duty, sexual issues \\
\hline & Political Differences & Political views \\
\hline & Demographics & Ages, where they are from, majors \\
\hline \multirow[t]{7}{*}{$\mathbf{L}$} & Good Job & Good, high paying job \\
\hline & Become teacher & Specific plans to become a teacher \\
\hline & Take care of self & Includes good health, fulfillment on job \\
\hline & Hard working & Earn a reputation as a hard worker \\
\hline & Marry well & Marry well in terms of a good match, being happy, financially secure. \\
\hline & Student sets goals & Leave goals to the student - no influence from parents \\
\hline & Set role expectation & Expectation that women pursue a "good job for a woman" like a teacher. \\
\hline
\end{tabular}

